\title{
Ecology, status and conservation of the Red-fronted Macaw Ara rubrogenys
}

\author{
ELIN PITTER and METTE BOHN CHRISTIANSEN
}

\section{Summary}

A five-month study of the Red-fronted Macaw Ara rubrogenys, endemic to Bolivia, yielded a population estimate of $2,000-4,000$ individuals. The species is resident and locally common in, but restricted to, an area in the drainage systems of the Río Grande, Rio Mizque and northern Río Pilcomayo. One-third of the population was composed of juveniles some three months after the end of the breeding season. During the dry season, with food apparently short, more of the day was spent feeding than during the wet season. Semi-deciduous vegetation along the rivers produced fruits and seeds that sustained the macaws during the dry season, but the conversion of such areas to arable land forces the macaw to depend for some months on crops and weeds. Local farmers consider the macaw a serious pest on maize.

Un estudio de cinco meses del Guacamayo Dorado Ara rubrogenys, especie endémica de Bolivia, dió como resultado la estimación de una población de entre 2,000 a 4,000 individuos. Esta especie es sedentaria, de facil localización pero restringida a las áreas de los sistemas de drenage de los ríos: Río Grande, Río Mizque y al norte de Río Pilcomayo. Tres meses después de la terminación de la época de la reproducción una tercera parte de la población está compuesta por juveniles. A lo largo de la estación seca aparentemente escacean los alimentos, pero es en ésta época en que los guacamayos dedican más tiempo a alimentarse, que durante la estación húmeda. La vegetación semidecídua en las riveras de los ríos proporcionaba los frutos y las semillas que sustentaban a los guacamayos durante la sequía, pero la conversión de dichas áreas a terrenos cultivables, han obligado a los guacamayos a depender por algunos meses de las cosechas de los agricultores y de algunas hierbas. Los agricultores de la región consideran a lo guacamayo como una plaga para el maíz.

\section{Introduction}

Only a few macaw species are predominantly associated with an arid habitat, notably Red-fronted Ara rubrogenys, Lear's Anodorhynchus leari and Spix's Cyanopsitta spixii, all of which have small populations and restricted ranges and are considered at risk of extinction (for reviews of these species see Collar et al. 1992). The total population of the Red-fronted Macaw, endemic to south-central Bolivia, was estimated by Ridgely (1981) to be only 1,000-3,000 birds, whereas Lanning (1982, 1991), having found the species to extend more widely than previously known, estimated 3,000-5,000 birds. The range includes the basins of the Ríos Mizque and Grande, plus at least the northern extreme of the Río Pilcomayo valley, and represents the northern half of the montane, mainly 
deciduous, temperate and subtropical forest in the Bolivian Valles (Hueck 1966, Hueck and Seibert 1972, Montes de Oca 1989). J. Fjeldså and S. Mayer did not find it in similar dry forest habitat south of $20^{\circ} 38^{\prime} \mathrm{S}$ on the Río Pilcomayo, and local people there did not know the species (J. Fjeldså verbally).

The macaw is threatened by habitat destruction, trapping for the pet industry and, to a lesser extent, persecution by local farmers. It has been the subject of studies by Ridgely (1981), Lanning (1982, 1991), Clarke and Duran Patiño (1991) and Boussekey et al. (1991). The purpose of our own work was to collect more information on the macaw's feeding ecology, social grouping, habitat requirements and status (see also Christiansen and Pitter 1993a,b), in order to plan appropriate conservation measures.

\section{Study area}

The study area was located in the valleys of the eastern cordillera in southcentral Bolivia at 1,000-2,500 m (Solomon 1989; see Figure 1), where the annual rainfall is between 300 and $800 \mathrm{~mm}$, the majority falling from December to April (Hueck 1966, Hueck and Seibert 1972, Montes de Oca 1989). The vegetation was temperate and subtropical dry forest and woodland (Montes de Oca 1982). The forest was mainly deciduous, but patches of semi-deciduous forest were found in the river valleys; common trees were Acacia sp., Prosopis kuntzei, P. cf. chilensis, Tipuana speciosa, Schinus molle, Aspidosperma quebracho-blanco, Loxopterygium grisebachii, Schinopsis haenkeana and many cacti such as Browningia caineana, Yungasocereus inquisivensis, Opuntia cochabambensis, Harrisia tetracantha, Cereus sp., Cleistocactus parviflorus and Neoraimondia herzogiana. Most trees were 7-12 m tall.

The area had been heavily degraded by logging for firewood and charcoal production, clearing for new agricultural land, and grazing by cattle and goats. The landscape consequently offered a mosaic of agricultural land, scrubby areas and forest heavily influenced by the activities of humans and domestic animals. The majority of the trees were less than 30 years old (S. Arias verbally).

Our main efforts were concentrated around Sucusuma (Potosí province), a small community on the Río Caine $(8 \mathrm{~km}$ north of Torotoro), and in an area 2$25 \mathrm{~km}$ south of Puente Arce (Chuquisaca province) on the Río Chico, a tributary of the Río Grande (Figure 1), the two areas being c.90 km apart. Sucusuma appears to be the area investigated previously by Boussekey et al. (1991).

The area around Sucusuma is located between $18^{\circ} 02-08^{\prime} \mathrm{S}$ and $65^{\circ} 38-46^{\prime} \mathrm{W}$, at $1,960-2,700 \mathrm{~m}$, and was characterized by large agricultural plots in the valleys previously covered with semi-deciduous forest (which survived in only a few small valleys). On the hillsides a young sparse forest and scrub vegetation was found. In October, all the trees on the hillsides had lost their leaves.

The area along the Río Chico is located between $18^{\circ} 37-45^{\prime} \mathrm{S}$ and $65^{\circ} \mathrm{o} 8-10^{\prime} \mathrm{W}$, at $1,600 \mathrm{~m}$. The deciduous forest on the mountain slopes bordering the narrow riverbed was less influenced by human activities than at Sucusuma: the valley is much narrower, leaving less land suitable for agriculture. On the western side of the Río Chico many ravines were filled with tall vegetation, while the eastern side had ravines surrounded by high cliffs with an abundance of holes suitable for nesting. 


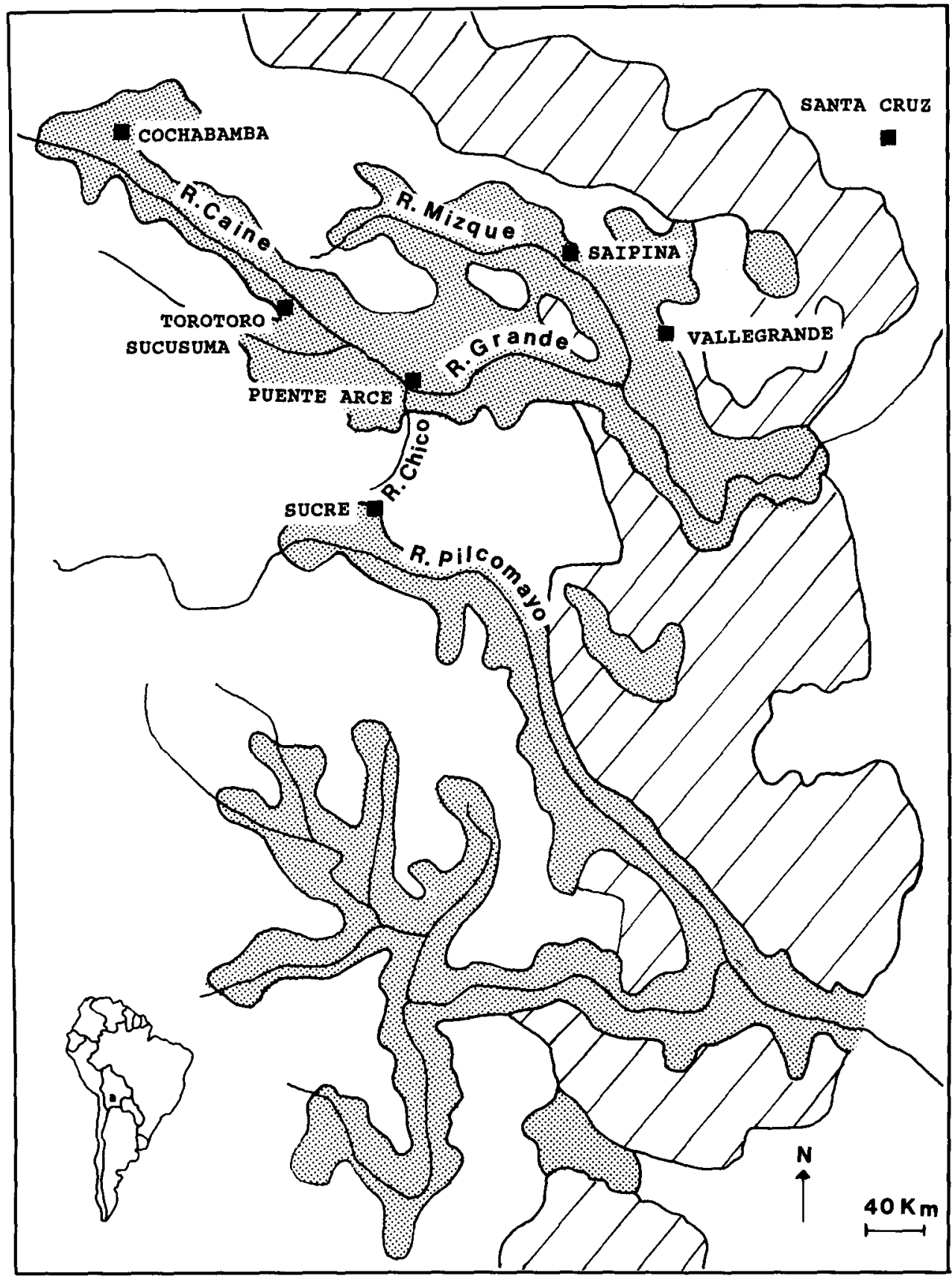

Figure 1. Vegetation of south-central Bolivia. Stippling, dry forest in the arid intermontane valleys; stripes, Tucumán-Bolivian forest; white, vegetation west of the intermontane valleys, consisting of montane and subalpine forest, steppe and scrub; vegetation to the east is dry forest of the Chaco. Redrawn from Hueck and Seibert (1972). 
At Sucusuma the main crop was maize Zea mays and peanuts Arachis hypogaea, while along the Río Chico it was maize. Furthermore, some areas at Río Chico were used for agroforestry with a large element of fruit trees, such as mango Mangifera indica, guava Psidium guajaba, various species/cultivars of citrus fruits Citrus spp., and Inga edulis.

\section{Methods}

Fieldwork was conducted from September 1991 to March 1992. During 22 days from the end of November to 18 December, we carried out a survey by vehicle over a distance of $550 \mathrm{~km}$ (Figure 2) in parts of the macaw's range as given by Lanning (1982) and Clarke and Duran Patiño (1991). Through daily observation from the vehicle and while hiking, and especially through interviews with the local people, we collected information about the status of the species. We undertook fieldwork around Sucusuma from 24 September to 21 October. Fieldwork along the Río Chico lasted from 26 December to the end of February.

In both areas we noted habitat use by the macaws during the day: location of feeding, drinking and resting areas. Where possible, in all activities the flock size as well as the number of adults and juveniles was recorded, the juveniles

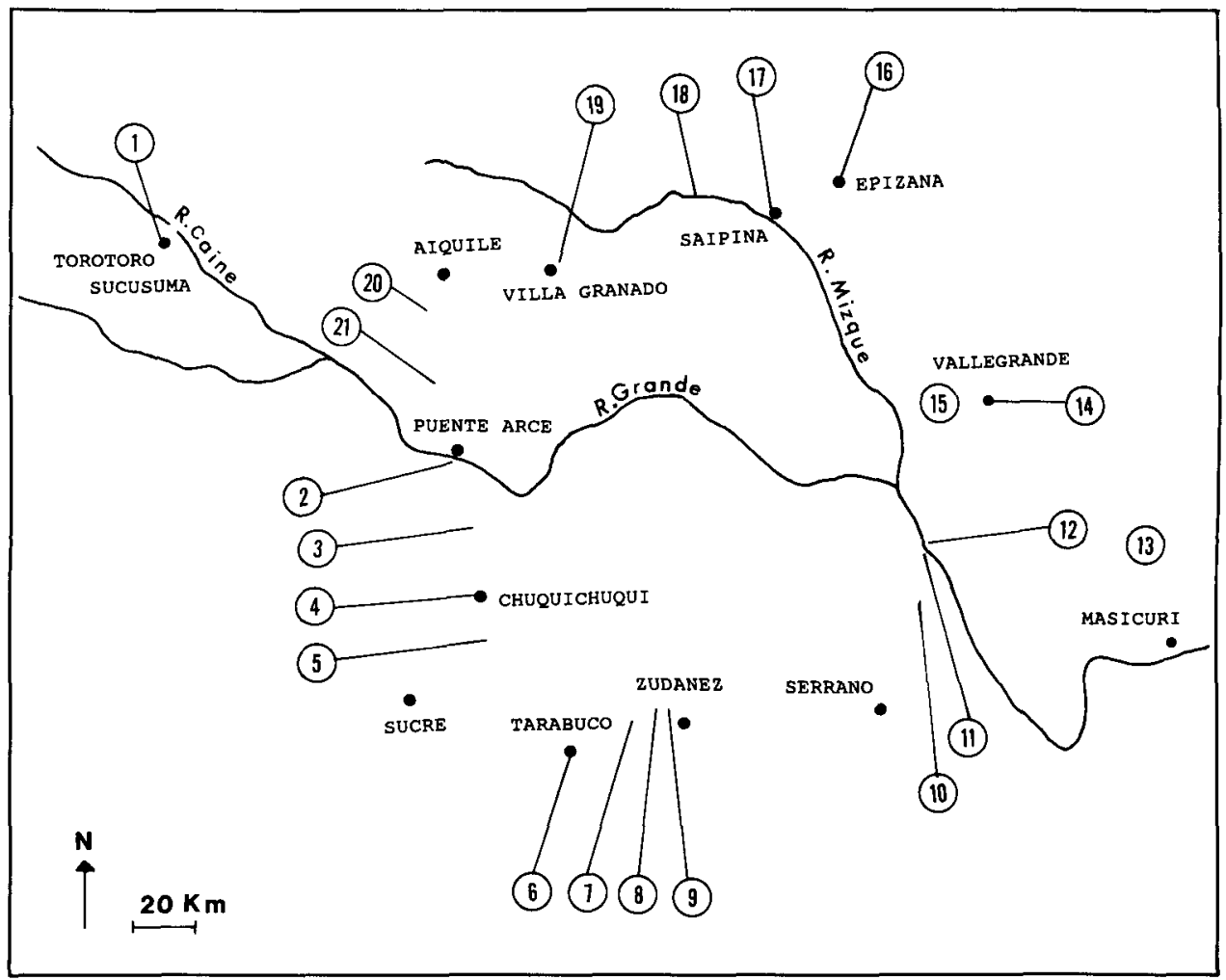

Figure 2. Personal observations and local reports of Red-fronted Macaws, September 1991 to March 1992. Numbers refer to discrete areas but are not identified further here, although some are mentioned in the text. 
being identified by the less developed orange/red feather patches on forehead, wings and thighs. During a feeding period the number of birds feeding together varied considerably, as birds arrived and left continuously, and for each flock we therefore recorded the maximum number of birds.

We collected data on diet and feeding rate. Disturbances of all kinds were noted as well as the birds' reaction and the distance from them of the source of the disturbance. In Río Chico interviews with local people were conducted in Quechua by S. Arias and E. Villegas, and we made particular use of their information about the macaw's feeding habits during the year, including crop damage and persecution. During our vehicle survey we gathered information on the status of the macaw from local people who could speak Spanish and recognize an illustration of the species.

\section{Results}

\section{Status}

The Red-fronted Macaw seemed to be locally common in most parts of the range that we visited (Figure 2). During the vehicular survey (chiefly December 1991) we observed 35 macaws at Puente Arce (no.2), 12 at lower Río Grande (nos.11-12), 11 in the larger agricultural area in the valley north of Vallegrande (no.14), seven in an area $30 \mathrm{~km}$ west of Vallegrande and close to Río Mizque (no.15), 21 in the agricultural area at Saipina (no.17), and four $15 \mathrm{~km}$ west of Saipina on the Río Mizque (no.18).

According to local people, the Red-fronted Macaw was common at the following localities: nos.3-5 (Río Chico), no.8 (Río Jatún Mayu), no.9 (Río Zudáñez), no.19 (Río Pabellón) and no.20 (50 km north of Puente Arce). We were informed that in some areas the birds did not occur all year round, but arrived in large flocks during the maize season. This included the areas of Tarabuco (no.6), Zudáñez (no.7), Vallegrande (no.14), Epizana (no.16), Saipina (no.17) and west of Saipina (no.18). The macaws even came to forage in fields in humid areas up to $8 \mathrm{~km}$ from the nearest dry habitat they normally used (no.10).

South of Vallegrande the habitat of the macaw (the dry forest shown in Figure 1) continued in a narrow zone along the Río Grande, flanked on both sides by humid forest occupied by the Military Macaw Ara militaris. The latter's distribution covers both arid and humid areas (Fjeldså et al. 1987, Forshaw 1989), but in areas of Bolivia where the two species approach the Red-fronted occupies the arid and the Military the humid habitat. We recorded 27 of the latter flying to roost close to Masicuri (no.13). Red-fronteds only venture into the adjacent humid areas during the maize season, and this is presumably an adaptation of their normal ranging behaviour as a result of man-made alterations to the environment.

In the Sucusuma area (no.1), based on maximum flocks seen (on one occasion we counted 90 macaws congregating in the same field to feed) and owing to a clear impression that the birds observed a regular daily pattern, we estimate the local population to be at least 100 individuals over a $25 \mathrm{~km}$ stretch along the Río Caine. A third of the population was composed of juveniles. Of a total of 399 observations of pairs, $44 \%$ had no offspring, $29 \%$ had one, $16 \%$ had two, 
and $11 \%$ had three offspring. In the Río Chico area (no.2) the daily pattern was less obviously fixed and we counted concentrations of more than 20 birds; we consequently estimate the population along $20 \mathrm{~km}$ of the river south of Puente Arce to have been around 50 birds. We observed $14 \%$ juveniles and $86 \%$ adults $(n=131)$.

From the information and observations above $\left(2.5^{-4}\right.$ individuals on a $1 \mathrm{~km}$ stretch of river), as well as from an estimate of suitable feeding areas for the macaw (evergreen valleys as well as valleys with farmland) in the river valleys of the Ríos Grande, Mizque and Pilcomayo (personal observations plus evidence from 1:250,000 maps), we assessed the total population of the Red-fronted Macaw to be 2,000-4,000 birds.

\section{Pattern of daily activity, roosting and habitat requirements}

It appeared that the only terrain suitable for the macaws was along river valleys, and through fieldwork and the use of maps we estimated that during the period of study the home range of the local population at Sucusuma was about $50 \mathrm{~km}^{2}$, including roosting, feeding, resting and nesting areas (Figure 3). Within this home range the macaws followed a set pattern of daily activities and usually returned to the same roosts each evening. The daily pattern observed at Sucusuma was much more pronounced than in the Río Chico area, where the greater availability of food during the period of study appears to have allowed more time for other activities.

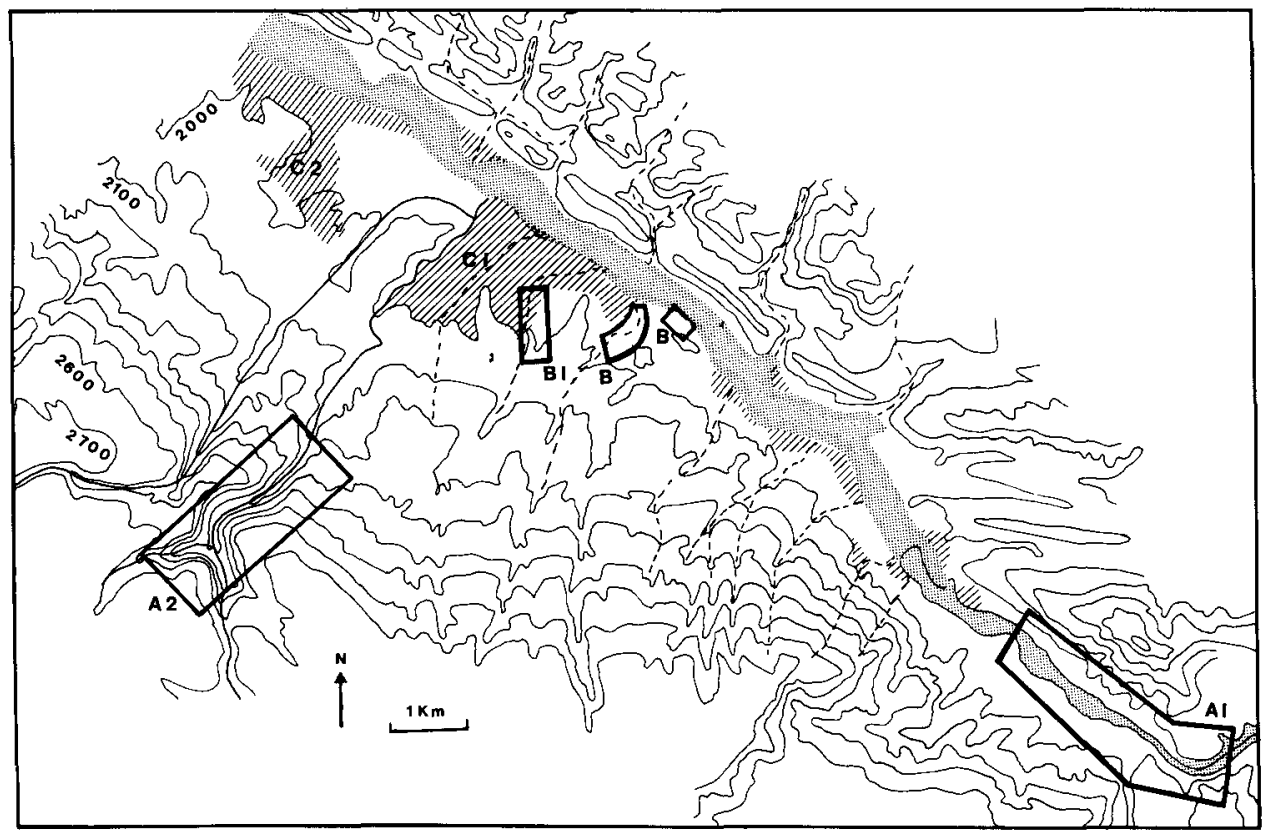

Figure 3. The study area at Sucusuma. $A_{1}$ and $A_{2}$, roosting areas; $B_{1}, B_{2}$ and $B_{3}$, resting areas; $C_{1}$ and $C_{2}$, feeding areas. 
Roosting Generally the macaws roosted in undisturbed cliff areas away from human settlements, on ledges which were protected from rain and wind by overhanging rocks; however, we twice noted a small group of macaws roosting in trees near feeding areas.

During morning and evening counts at Sucusuma we observed the local population of around 100 birds using two cliff areas, A1 and A2 (Figure 3), for roosting. Both areas were located near rivers (Río Caine and a tributary thereof called the Río Sucusuma) and both had vertical cliffs, 50-100 m (A1) and $200 \mathrm{~m}$ (A2) high respectively, rising on both sides of the rivers, leaving only a narrow passage of $c .50 \mathrm{~m}$. The roost sites were located approximately $11-15 \mathrm{~km}$ (A1) and $6 \mathrm{~km}$ (A2) from the feeding areas $\mathrm{C} 1$ and $\mathrm{C} 2$ (which are at $1,960 \mathrm{~m}$ and hold the majority of the region's farmers). The number of macaws that spent the night in each roosting area varied from night to night. The roosting areas were also used by Blue-fronted Amazons Amazona aestiva, Mitred Conures Aratinga mitrata, Blue-crowned Conures Aratinga acuticaudata and Monk Parakeets Myiopsitta monachus luchsi.

The macaws started to leave the roosts after first light, but before the sun rose over the mountain ridges. At Sucusuma birds continued to leave the roost in groups over a period of half-an-hour. They returned to the roosts just before dark (between 18 hoo and 19hoo).

Feeding and drinking At Sucusuma the birds usually left directly for the feeding areas, while along the Río Chico they often first flew to trees in which they perched briefly or sometimes for up to several hours before setting out for the feeding grounds (Figure 4a). In this period before feeding they were generally very restless, moving around on branches, flying between the trees calling loudly, or auto- and allopreening, playing and fighting.

The macaws usually fed twice a day (Figure $4 b$ ). At Sucusuma the feeding periods were limited to certain hours, from o6hoo to rohoo (mainly o6hoo-oghoo) and from 14 hoo to 19 hoo (mainly 16 hoo-18hoo). Along the Río Chico a similar pattern was seen, although the two periods were not as well separated as at Sucusuma. Depending on the availability and type of food, the birds spent from one or two (Río Chico) to four (Sucusuma) hours daily feeding. Within the feeding period they carried out other activities as well.

After feeding, the macaws often flew off to drink. At Sucusuma drinking appeared to be limited to two periods, whereas in Río Chico it took place throughout the day (Figure $4 \mathrm{c}$ ). They went to the riverbed to drink from small ponds or small, less turbulent streams along the river.

Resting During the hot midday hours the birds perched in shady trees. Usually they congregated near feeding areas in quiet valleys or gorges through which people rarely passed. In both cases they used native, semi-deciduous vegetation with tall $(7-9 \mathrm{~m})$ trees. Trees fulfilling these requirements were Schinopsis, Tipuana, Loxopterygium, Aspidosperma and various species of Acacia.

At Sucusuma the macaws rested from around oghoo to 14hoo-16hoo. Along the Río Chico there was no defined resting period and birds could be seen resting at any time of the day. For breeding males and probably also for the 
A

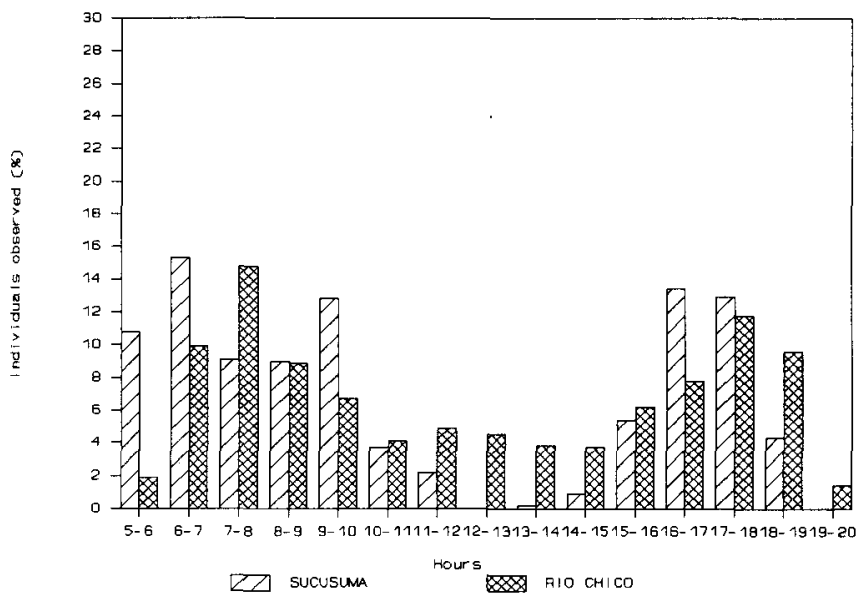

B

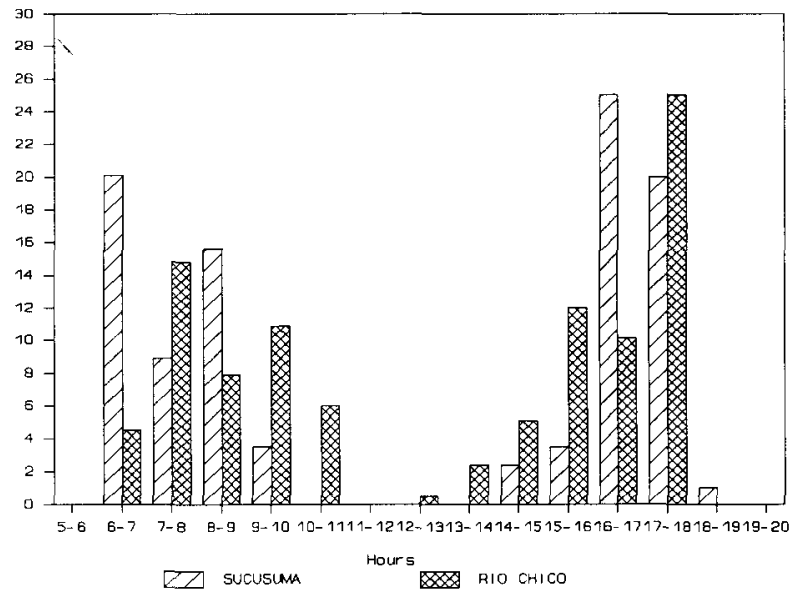

C

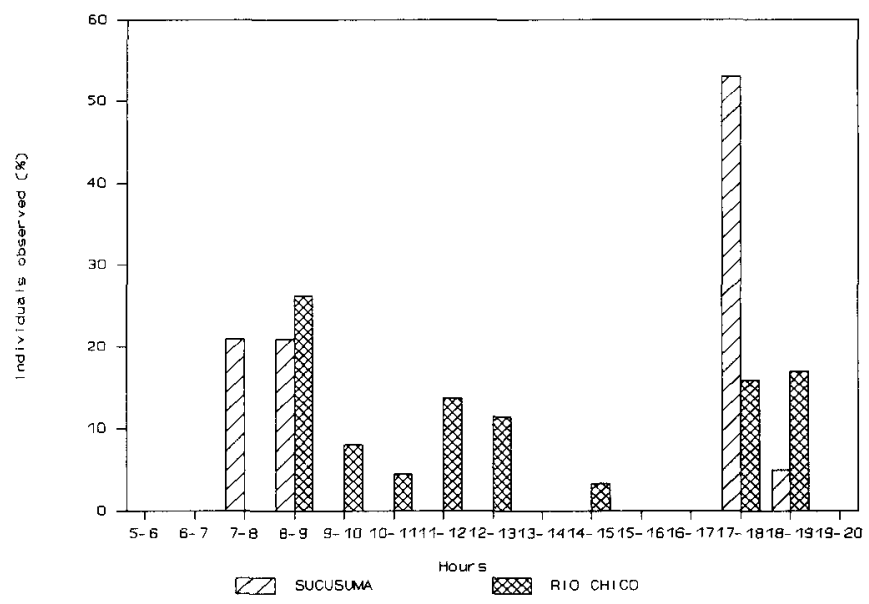

Figure 4. Daily pattern in Red-fronted Macaws of A flying, B feeding and C drinking. https://doi.org/18.1017/10959270900002951 Published online by Cambridge University Press 
Table 1. Frequency distribution of Red-fronted Macaw flock sizes while flying, feeding, drinking or resting (in the same tree) in the two study areas

\begin{tabular}{|c|c|c|c|c|c|c|c|c|}
\hline \multirow[t]{2}{*}{ Number of birds } & \multicolumn{2}{|c|}{ Flying (\%) } & \multicolumn{2}{|c|}{ Feeding (\%) } & \multicolumn{2}{|c|}{ Drinking (\%) } & \multicolumn{2}{|c|}{ Resting (\%) } \\
\hline & Suc & $\mathrm{R} \mathrm{Ch}$ & Suc & $\mathrm{R} \mathrm{Ch}$ & Suc & $\mathrm{R} \mathrm{Ch}$ & Suc & $\mathbf{R} \mathrm{Ch}$ \\
\hline 1 & 6 & 8 & 0 & 0 & 0 & 0 & 0 & \\
\hline 2 & 28 & 51 & 6 & 32 & 20 & 22 & 9 & \\
\hline 3 & 17 & 9 & 7 & 0 & 7 & 22 & 9 & \\
\hline 4 & 17 & 13 & 6 & 8 & 13 & 22 & 10 & \\
\hline 5 & 12 & 6 & 3 & 11 & 7 & 0 & 19 & \\
\hline $6-10$ & 13 & 10 & 12 & 24 & 46 & 35 & 38 & \\
\hline $11-15$ & 5 & 3 & 16 & 11 & 7 & 0 & 12 & \\
\hline $16-20$ & 4 & o & 19 & 8 & o & o & 2 & \\
\hline $21-25$ & $\mathbf{I}$ & $o$ & 12 & 5 & o & $o$ & $o$ & \\
\hline $26-30$ & $\mathrm{o}^{*}$ & o & 4 & 0 & o & o & o & \\
\hline $31-35$ & o & o & 4 & 0 & o & o & 0 & \\
\hline $36-40$ & 0 & 0 & $I$ & 0 & o & $o$ & 0 & \\
\hline$>40$ & 0 & 0 & 9 & 0 & 0 & $o$ & $o$ & \\
\hline
\end{tabular}

Suc., Sucusuma; $\mathrm{R}$ Ch., Río Chico. ${ }^{*}$ indicates that percentage is $<1$.

birds resting in the same gorge as the breeding males, the resting period could last almost all day, only interrupted by short visits to the feedings areas.

\section{Daytime flock sizes in relation to different activities}

Flock size varied with type of activity. Single birds were rarely seen. When flying, the macaws were most often observed in pairs or family groups of 35 individuals, and while feeding, drinking, resting or roosting they usually congregated in larger groups (Table 1). Pairs or family groups forming part of large flocks stayed closely together as units. Large flocks were not very stable and soon disintegrated.

The foraging flocks at Sucusuma were much larger than the flocks along the Río Chico (Tables 1,2). The macaws often arrived in small groups from different directions during a short period and congregated in a certain feeding area.

Table 2. Red-fronted Macaw flock size in different activities

\begin{tabular}{|c|c|c|c|c|c|c|}
\hline \multirow[b]{2}{*}{ Activities } & \multicolumn{3}{|c|}{ Sucusuma } & \multicolumn{3}{|c|}{ Río Chico } \\
\hline & $\begin{array}{l}\text { Mean } \\
\text { flock size }\end{array}$ & Range & $\begin{array}{l}\text { Number of } \\
\text { observations }\end{array}$ & $\begin{array}{l}\text { Mean } \\
\text { flock size }\end{array}$ & Range & $\begin{array}{l}\text { Number of } \\
\text { observations }\end{array}$ \\
\hline Roosting & 45 & $16-68$ & 12 & & & \\
\hline Leaving roosts & 5 & $1-26$ & 100 & & & \\
\hline Non-roost flights & 4 & $1-30$ & 402 & 3 & $1-15$ & 595 \\
\hline $\begin{array}{l}\text { Arrival in feeding } \\
\text { areas }\end{array}$ & 6 & $1-40$ & 176 & 3 & $1-12$ & 67 \\
\hline $\begin{array}{l}\text { Feeding on Cenchrus } \\
\text { and peanuts }\end{array}$ & 19 & $2-86$ & 68 & & & \\
\hline Feeding on corn & & & & 6 & $2-20$ & 17 \\
\hline Feeding on Jatropha & & & & 8 & $2-24$ & 20 \\
\hline Drinking & 5 & $2-9$ & 9 & 6 & $2-12$ & 15 \\
\hline Resting in trees & 7 & $2-18$ & 58 & & & \\
\hline
\end{tabular}


Several macaws often sat in close proximity while feeding. In Jatropha trees, which have an abundance of fruit, the macaws often fed within a distance of only $20-50 \mathrm{~cm}$ of each other, only rarely displaying any aggression. At Sucusuma, where food was sparsely distributed, they also fed very closely.

\section{Food and feeding}

Comparison of data gathered by direct observation with information contributed by local people along the Río Chico indicates that from January to February the macaws in that area fed mainly on maize and Jatropha (present often in pure stands in ravines, but interspersed with other vegetation on mountain slopes), with the latter remaining the chief food until May. Jatropha fruits contain $17 \%$ proteins and $33 \%$ fats (dry matter). From April to October the birds fed on the seeds of Loxopterygium, Aspidosperma, Tipuana and Schinopsis, all of whose fruits are unripe in February; during this period a new maize crop becomes available. From October to January the birds mainly feed on Ziziphus fruits.

During our period of study at Sucusuma, the macaws were only seen feeding in the valleys along the Río Caine. In most of the larger valleys agriculture had replaced the natural semi-deciduous vegetation, and the macaws fed almost exclusively in the harvested fields for the remaining peanuts and for the very common seeds of the weed Cenchrus sp. Very occasionally they fed on native fruit such as pods of two Prosopis species. Of these $P$. cf. chilensis was very common and $P$. kuntzei much less so, but most were either without fruit that year or with fruit that was still unripe. In general the amount of native fruit seemed to be very limited, and the native trees with fruit available seemed to be found in the very few remnants of semi-deciduous vegetation in the valleys. Deciduous vegetation on the hillsides hardly carried any fruits at that time of year.

Altogether, we observed macaws feeding on seven species of native fruit and seed, and on two types of crop (Table 3). Local inhabitants added some other items, including ones used outside the study period; but we treat some of their information with caution (Table 4).

At Sucusuma Schinus was the only tree species bearing plenty of fruit during our study, but we never saw them being taken. At Río Chico Cnidoscolus albomaculatus and Celtis sp. were very common and rich in fruit from February possibly into April, but while Blue-crowned and Mitred Conures Aratinga acuticaudata and $A$. mitrata exploited this resource, the macaws never showed any interest in it.

Macaws were occasionally seen biting or chewing on various unripe fruits, and on leaves, twigs or branches. In October leaves and in February an unripe pod of Aspidosperma were seen being chewed; also in February the unripe fruits of Loxopterygium and Anadenanthera colubrina were respectively chewed by two juveniles. Groups of noisy birds were seen biting off twigs $(30-40 \mathrm{~cm})$ of Schinopsis on four occasions, and once an adult pair chewed on the thick juicy bases of a Tillandsia sp. We recorded 18 instances of birds chewing pieces of sandstone on cliffs.

Under good foraging conditions for Cenchrus seeds (i.e. when the birds had little walking to do to find them), the encounter rate was up to 32 seeds per 
Table 3. Use of food plants by Red-fronted Macaws from September to March

\begin{tabular}{|c|c|c|c|c|}
\hline $\begin{array}{l}\text { Species } \\
\text { Family }\end{array}$ & Locality & No. of obs. & Period of obs. & $\begin{array}{l}\text { Habit/ } \\
\text { Type of fruit/ } \\
\text { Size of fruit/ } \\
\text { Stage eaten }\end{array}$ \\
\hline $\begin{array}{l}\text { Cenchrus sp. } \\
\text { Gramineae }\end{array}$ & Sucusuma & 68 & Oct & $\begin{array}{l}\text { Grass } \\
\text { Seed } \\
0.2 \mathrm{~cm} \\
\text { Ripe }\end{array}$ \\
\hline $\begin{array}{c}\text { Arachis hypogaea } \\
\text { Leguminosae }\end{array}$ & Sucusuma & $68^{\mathrm{a}}$ & Oct & $\begin{array}{l}\text { Herb } \\
\text { Pod } \\
\text { Ripe }\end{array}$ \\
\hline $\begin{array}{l}\text { Prosopis kuntzei } \\
\text { Leguminosae }\end{array}$ & Sucusuma & 2 & Oct & $\begin{array}{l}\text { Tree } \\
\text { Pod } \\
\text { 10-15 cm } \\
\text { Ripe }\end{array}$ \\
\hline $\begin{array}{l}\text { Prosopis } \\
\text { cf. chilensis } \\
\quad \text { Leguminosae }\end{array}$ & Sucusuma & 4 & Oct & $\begin{array}{l}\text { Tree } \\
\text { Pod } \\
15-25 \mathrm{~cm} \\
\text { Unripe }\end{array}$ \\
\hline $\begin{array}{l}\text { Ziziphus mistol } \\
\text { Rhamnaceae }\end{array}$ & $\begin{array}{l}\text { Río Chico and } \\
\text { further down } \\
\text { Río Grande }\end{array}$ & 5 & $\begin{array}{l}\text { Mid Oct- } \\
\text { Mid Dec }\end{array}$ & $\begin{array}{l}\text { Tree } \\
\text { Drupe } \\
1 \mathrm{~cm} \\
\text { Ripe }\end{array}$ \\
\hline $\begin{array}{l}\text { Zea mays } \\
\text { Gramineae }\end{array}$ & Río Chico & 25 & Mid Sep & $\begin{array}{l}\text { Grass } \\
\text { Spike } \\
\text { 10-20 cm } \\
\text { Ripe } \\
\text { Unripe }\end{array}$ \\
\hline $\begin{array}{l}\text { Jatropha sp. } \\
\text { Euphorbiaceae }\end{array}$ & Río Chico & 20 & Mid Dec-Feb & $\begin{array}{l}\text { Tree } \\
\text { Capsule } \\
4 \mathrm{~cm} \times 3.5 \mathrm{~cm} \\
(3 \text { seeds: } \\
2.5 \mathrm{~cm} \times 0.9 \mathrm{~cm}) \\
\text { Ripe }\end{array}$ \\
\hline $\begin{array}{l}\text { Schinopsis haenkeana } \\
\text { Anacardiaceae }\end{array}$ & Río Chico & 5 & Jan-Feb & $\begin{array}{l}\text { Tree } \\
\text { Samara } \\
\text { I cm } \\
\text { Ripe (fallen) }\end{array}$ \\
\hline $\begin{array}{l}\text { Capparis sp. } \\
\text { Capparidaceae }\end{array}$ & Río Chico & 1 & Feb & $\begin{array}{l}\text { Tree } \\
\text { Pod } \\
<10 \mathrm{~cm} \\
\text { Ripe }\end{array}$ \\
\hline
\end{tabular}

a On 68 occasions the macaws were observed foraging in harvested fields. The macaws mainly found Cenchrus sp., but occasionally they located Arachis hypogaea (peanuts).

minute (mean 11, based on 249 minutes of observation). Sometimes the birds appeared to invest considerable time in searching for peanuts, presumably because of their high nutritional value. Owing to disturbance and periods of resting, however, the effective feeding time in the fields at Sucusuma probably amounted to only two hours per day. 
Table 4. Food plants used by the Red-fronted Macaws according to local people

\begin{tabular}{ll}
\hline Family & Species \\
\hline Ulmaceae & Celtisisp. \\
Cactaceae & Neoraimondia herzogiana \\
& Cereus hankeanus \\
Capparidaceae & Capparis sp. \\
Leguminosae & Acacia sp. \\
& Inga edulis \\
& Caesalpinia sp. \\
& Tipuana speciosa \\
Zygophyllaceae & Erythrina sp. \\
Euphorbiaceae & Tribulus sp. \\
Anacardiaceae & Cnidoscolus albomaculatus \\
Apocynaceae & Schinus molle \\
\hline
\end{tabular}

The intensity with which Jatropha fruits were exploited was very variable, sometimes being undertaken with energy and focus (long periods of activity in one part of a tree), sometimes without apparent interest, a bird just moving about in the tree and dropping fruit on the ground, or taking a long time to eat a single item. Where all three seeds in the fruit were consumed, the handling time from detachment from the tree to consumption of the last seed was 15150 (mean $51, n=50$ ) seconds per fruit. On one occasion we observed 13 birds eating 89 fruits in 50 minutes (each bird eating on average seven fruits during the period, spending 438 seconds per fruit).

When feeding on maize the macaws might either detach the entire cob or balance on the stalk and consume the seeds in situ. On one occasion we witnessed 12 birds eating 17 cobs in 36 minutes. They spent 10-25 (mean 20, $n=$ 35) minutes per cob.

\section{Crop damage and deliberate disturbance}

Crops of maize in small unprotected fields were completely destroyed by macaws and probably other parrots by the end of January. Even in fields where people almost constantly watched their crops, the macaws inflicted partial losses. Local people considered them to be serious pests and in some areas farmers lace crops with poison or else shoot them, although probably not in very large numbers. Mostly the farmers' reaction was to chase off the birds by sound and gesticulation.

In September and October, after the peanut harvest, we saw people chasing off birds only on a few occasions. In contrast, as maize ripened people would chase birds away several times each day, by shouting at them and throwing stones. Stones invariably caused them to fly up and away; shouting sometimes prompted desertion of the site, but often resulted in birds merely flying to a perch to await the chance to redescend, and in some cases it had no effect on the feeding birds whatsoever. Maize was evidently a highly preferred food, 
since the macaws invested considerable time - several hours - in some of their attempts to obtain access to fields being defended by farmers.

\section{Incidental disturbance}

When birds were foraging, one individual often appeared to remain as sentinel. Certainly the macaws were often disturbed, not only while feeding in fields or on native fruit but also while resting in trees. The commonest cause of disturbance was passing people (24 occasions) and overflying raptors (11 occasions involving Crested Caracara Polyborus plancus, three for Turkey Vulture Cathartes aura, and one each for Black Vulture Coragyps atratus and King Vulture Sarcoramphus papa). Overflying vultures and caracaras caused the macaws to take off, but as soon as the macaws realized the birds represented no danger, they settled down and continued feeding. Where human presence was rare, e.g. in quiet valleys, the birds were more sensitive to incidental disturbance, with a fly-up distance of around $50 \mathrm{~m}$. In well-peopled areas, the distance at which a passer-by caused ground-foraging birds to fly up was generally less than $20 \mathrm{~m}$. Further than $20 \mathrm{~m}$ the birds either (a) flew away, (b) flew into a tree to sit stiffly watching the intruder (it often took up to 10 minutes before the birds had returned to the field), (c) took flight, circled, and realighted at the same spot, or (d) stopped eating and watched the intruder until feeding could safely be resumed. They paid no attention to passing traffic or nearby domestic animals; and on one occasion they followed a ploughing farmer at a distance of only a few metres.

\section{Predators}

Local farmers informed us that both Black-chested Buzzard-eagle Geranoaetus melanoleucos and Peregrine Falcon Falco peregrinus occasionally attack macaws. We once saw two of the former circling at an altitude of 1,000 $\mathrm{m}$, causing a flock of 60 foraging macaws to take wing. We twice witnessed Peregrine attacks on macaws, once aimed at a flying flock and once targeted on a bird that landed in a tree and escaped by swinging upside-down from a branch with open beak directed at the falcon. Peregrine Falcons were also seen several times in the roosting areas.

\section{Discussion}

\section{Distribution and vagrancy}

Red-fronted Macaws are strong flyers (Boussekey et al. 1991) and in some areas we were told by local people that at certain seasons they moved over large areas in search of maize. However, the majority of these areas were less than $30 \mathrm{~km}$ from larger rivers, so we expect that, rather than undertaking long movements, the species makes only relatively short excursions to maize fields in nearby areas. In general it seems to be resident (this was certainly the case at Sucusuma); the lack of records in similar habitat in southern Bolivia and northern Argentina also suggests this (J. Fjeldså verbally). 


\section{Population structure}

The much lower percentage of juveniles found along Río Chico compared with Sucusuma could be attributed to several factors such as availability of food, juvenile mortality, increased trapping of nestlings for the pet trade, and the fact that some of the juveniles had already attained adult plumage (the juveniles were around 3-4 months older along Río Chico).

In rainforest at Manu, Peru, Munn (1992) found that during the four months after the end of a breeding season only around $10 \%$ of individuals in family groups of macaws (Blue-and-yellow Ara ararauna, Scarlet $A$. macao and Red-andgreen $A$. chloroptera) were young birds, and these species were never seen with three offspring. The juveniles at Sucusuma were of similar age to those studied by Munn, so the productivity of the Red-fronted Macaw may be judged considerably higher, in the year in question.

Munn suggested that the low productivity of macaws in Manu was caused mainly by the shortage of nest-holes. In our study, suitable nest-holes seemed to be plentiful and we consider food shortage to be the most important limiting factor for Red-fronted Macaws. Food availability in the area is unpredictable, and the birds' productivity presumably varies in relation to food abundance, with as many as three offspring bearing witness to a year of relatively high levels of food availability (see Stearns 1976).

\section{Social grouping}

In almost all activities - feeding, drinking, resting and roosting - the Redfronted Macaw was observed in groups (Table 1). This was also noted by Boussekey et al. (1991) and is a general phenomenon among parrots (Forshaw 1989). Flock size varied in relation to season, probably because of variation in availability and distribution of food, as also suggested by Murton (1971). When food was abundant the foraging flocks were small and widely scattered, but when food was scarce the birds congregated.

The size of the feeding flocks we recorded at Sucusuma are larger than reported for most species of macaw feeding in humid habitats. However, many arid-country parrots often associate in large monospecific flocks (Forshaw 1989) and increased aridity seems to be linked with increased flock size in parrots (Brereton 1971). Apart from the scarcity of food at Sucusuma in September and October, the presence of predators may also have been a factor in the flocking behaviour recorded.

Dispersion of suitable nest-holes determined distance between breeding pairs, but if feasible the macaws would probably nest colonially, as we observed several active nests in the same cliff area, with a distance of only $12 \mathrm{~m}$ between two holes (Christiansen and Pitter 1993a).

\section{The effects of habitat alteration and disturbance on feeding}

The great majority of the food obtained by the macaws in both study areas was crops or seeds from arable weeds. Along the Río Chico the birds could feed on many native fruits as an alternative, but at Sucusuma hardly any native fruits 
were present. The low availability of fruit on the hillsides at Sucusuma in the dry season indicates that before human settlement the macaws were probably confined mostly to the semi-deciduous vegetation originally covering the valleys. Today, where the valleys are used for agriculture, the macaws are for some months highly dependent on the food they can find in the fields, namely small seeds of Cenchrus and some peanuts. Some other medium-sized and large parrots are also known to subsist on small seeds for part of the year (Taylor 1985, Rowley 1990). Brandt and Machado (1989) found that Lear's Macaw was dependent on maize during fruit shortages.

In both areas many of the native tree species that provide food for the macaws at other times of the year were among those cut most often for firewood and forage for livestock. These include Tipuana, Loxopterygium, Schinopsis and Ziziphus, while Prosopis kuntzei was very often cut and used for fencing around fields. The only native food source that did not seem to be threatened was Jatropha, as it occurs mainly in naturally disturbed habitat.

Generally, Red-fronted Macaws seem to be fairly opportunistic in their selection of food, probably as a function of its unpredictability. However, the cutting of trees has probably resulted in a shortage of native food, increasing the macaws' dependence on crops in the fields.

Along the Río Chico the birds greatly preferred maize, even when it was in short supply and a wide choice of abundant native fruit existed. Captive macaws of many species show this preference also (Low 1990). Long (1985) found that Cockatiels Nymphicus hollandicus also preferred cereal crops to grasses, being larger, easier to locate, more abundant and higher in energy content; this was unexpected, as he found that many other parrots fed mainly on cereal crops only when their usual foods had failed.

Among the native fruits along the Río Chico the macaws seemed to concentrate on one abundant fruit for a certain period and only occasionally select other, less common foods. They also seemed to prefer larger food items such as Jatropha to the small fruits of either Celtis or Cnidoscolus (see Table 3).

Maize also provides an important food supplement during the egg-laying season, starting in December-January (Lanning 1991, Christiansen and Pitter 1993a). When the young hatch, the adults will probably feed mainly on Loxopterygium, Tipuana and Schinopsis and possibly a new maize crop; many local people told us that the pairs arrived in the maize fields with their young.

Food availability also influenced the time spent foraging. Two periods of feeding separated by a midday break is the most commonly observed pattern in parrot species (Jones 1987, Brandt and Machado 1989, Forshaw 1989, Boussekey et al. 1991). In spite of an apparent food shortage at Sucusuma the macaws still had time for a long break over midday, but the very high temperatures at this time (up to $38^{\circ} \mathrm{C}$ ) would preclude high activity. In particular, the effect of temperature would be pronounced on exposed soil in a field. Along the Río Chico the macaws spent little time searching for food; they normally had ample time to eat the required amount, and they often seemed to take longer than necessary on each fruit.

Accidental disturbance and chasing away of foraging macaws could influence the amount of food the birds obtained during the day, especially if the disturbance caused them to fly away or if they took time to recover their confidence 
before descending again. At Sucusuma disturbance probably affects the species adversely, because of the scarcity of food and alternative foraging areas. Along the Río Chico the persecution of the macaws in the maize fields was of less importance as there were plenty of feeding alternatives.

\section{Conclusions}

The future of the Red-fronted Macaw depends very much on the management of its habitat. In spite of being locally common, the situation could change rapidly. We consider the three most serious current threats to be habitat destruction, trapping for the pet trade, and persecution.

Clarke and Duran Patiño (1991) estimated that $40 \%$ of the species's habitat had already been destroyed. The need for agricultural land as well as firewood for domestic use, mining or sugar-cake production is still increasing, and causes continuing deforestation. Everywhere ground cover and regeneration are seriously impaired by overgrazing by goats and cattle. At Sucusuma and along the Río Chico there were very few places suitable for farming, and the best areas were located near the river, coinciding with the areas of semi-deciduous vegetation which we judge to be the original foraging habitat of the macaw.

The Red-fronted Macaw was placed on Appendix I of CITES in 1983, and all capture, transport and export of Bolivian wildlife was prohibited by Supreme Decree 21312 of 27 June 1986 (Fuller et al. 1987). However, according to local bird trappers near Vallegrande and along the Río Chico, both adult and nestling macaws are still being captured illegally. One of the trappers claimed that the local population of macaws had declined during the last 12 years owing to both excessive trapping and habitat destruction.

The importance of conserving the remaining vegetation in the valleys and replanting native trees cannot be emphasized strongly enough, not only for the conservation of the parrots but also to provide for the needs of local human communities. In order to conserve the native vegetation as well as water supplies, we suggest that both the valleys and the mountain slopes should be divided into strictly defined areas, some allocated for agriculture and others for grazing or firewood-cutting. Fencing-in certain areas would allow regrowth of the native vegetation, and this could provide sufficient native food for the macaws during months of food shortage, and as an alternative to maize; birdscaring devices to deflect birds from maize depredation would then be appropriate.

A large number of international agencies and NGOs are already working on various development projects in the area. Our suggestions could be accommodated into their work, along with an increased programme of education and training in environmental protection and the sustainable use of local resources.

\section{Acknowledgements}

We greatly appreciate the commitment and advice of ABPA (Asociación Boliviana para la Protección de las Aves) and Saúl Arias and Elva Villegas for assistance during part of the fieldwork, in particular for plant collections. We are also grateful to the staff of the Royal Botanic Gardens, Kew, and in particular Nigel 
P. Taylor and Dr Daniela C. Zappi for plant identifications. We thank Dr Jon Fjeldså and José Maria Cardoso da Silva for helpful comments on a draft, and Birger Graa for linguistic corrections. We gratefully acknowledge the financial support of WWF-World Wide Fund for Nature, Denmark, and of the municipality of Nr. Alslev.

\section{References}

Boussekey, M., Saint-Pie, J. and Morvan, O. (1991) Observations on a population of Red-fronted Macaws Ara rubrogenys in the Río Caine valley, central Bolivia. Bird Conserv. Internatn. 1: 335-350.

Brandt, A. and Machado, R. B. (1989) Study of the feeding area and feeding behavior of the Lear's Macaw. Unpublished.

Brereton, J. le G. (1971) Inter-animal control of space. Pp.69-91 in A. H. Esser, ed. Behavior and environment: the use of space by animals and men. New York: Plenum Press.

Christiansen, M. B. and Pitter, E. (1993a) Aspects of breeding behaviour of Red-fronted Macaws, Ara rubrogenys, in the wild. Gerfaut 82-83: 51-61.

Christiansen, M. B. and Pitter, E. (1993b) Aspects of behaviour of juvenile Red-fronted Macaws, Ara rubrogenys, in the wild. Gerfaut 82-83: 63-69.

Clarke, R. O. S. and Duran Patiño, E. (1991) The Red-fronted Macaw Ara rubrogenys in Bolivia: distribution, abundance, biology and conservation. Unpublished.

Collar, N. J., Gonzaga, L. P., Krabbe, N., Madroño Nieto, A., Naranjo, L. G., Parker, T. A. and Wege, D. C. (1992) Threatened birds of the Americas: the ICBP/ILCN Red Data Book (Third edition, part 2). Cambridge, U.K.: International Council for Bird Preservation.

Fjeldså, J., Krabbe, N. and Ridgely, R. S. (1987) Great Green Macaw Ara ambigua collected in northwest Ecuador, with taxonomic comments on Ara militaris. Bull. Brit. Orn. Club 107: 28-31.

Forshaw, J. M. (1989) Parrots of the world. Third revised edition. Willoughby, Australia: Lansdowne Editions.

Fuller, K. S. and Gaski, A. (1987) Update to Latin American wildlife trade laws. Washington, D.C.: World Wildlife Fund.

Hueck, K. (1966) Die Wälder Südamerikas. Stuttgart: Gustav Fischer Verlag.

Hueck, K. and Seibert, P. (1972) Vegetationskarte von Südamerika. Stuttgart: Gustav Fischer Verlag.

Jones, D. (1987) Feeding ecology of the Cockatiel, Nymphicus hollandicus, in a graingrowing area. Austral. Wildl. Res. 14: 105-115.

Lanning, D. V. (1982) Survey of the Red-fronted Macaw Ara rubrogenys and Caninde Macaw Ara caninde in Bolivia, December 1981-March 1982. Unpublished.

Lanning, D. V. (1991) Distribution and breeding ecology of the Red-fronted Macaw. Wilson Bull. 103: 357-365.

Long, J. L. (1985) Damage to cultivated fruit by parrots in the south of Western Australia. Austral. Wildl. Res. 12: 75-80.

Low, R. (1990) Macaws: a complete guide. London: Merehurst.

Montes de Oca, I. (1989) Geografia y recursos naturales de Bolivia. La Paz: Academia Nacional de Ciencias de Bolivia.

Munn, C. A. (1992) Macaw biology and tourism, or "when a bird in the bush is worth two in the hand". Pp.47-72 in S. R. Beissinger and N. F. R. Snyder, eds. New World parrots in crisis: solutions from conservation biology. Washington, D.C.: Smithsonian Institution Press.

Murton, R. K. (1971). Why do some bird species feed in flocks? Ibis 113: 534-536. 
Ridgely, R. S. (1980) The current distribution and status of mainland Neotropical parrots. Pp.233-384 in R. F. Pasquier, ed. Conservation of New World parrots. Washington, D.C.: Smithsonian Institution Press for the International Council for Bird Preservation.

Rowley, I. (1990) Behavioural ecology of the Galah Eolophus roseicapillus in the wheatbelt of Western Australia. New South Wales: Surrey Beatty and Sons.

Solomon, J. C. (1989) Bolivia. Pp.455-463 in D. G. Campbell and H. D. Hammond, eds. Floristic inventory of tropical countries. New York: New York Botanical Garden.

Stearns, S. C. (1976) Life history tactics: a review of the ideas. Q. Rev. Biol. 51: 3-47.

Taylor, R. H. (1985) Status, habits and conservation of Cyanoramphus parakeets in the New Zealand region. Pp.195-211 in P. J. Moors, ed. Conservation of island birds. Cambridge, U.K.: International Council for Bird Preservation (Techn. Publ. 3).

E. PITTER and M. B. CHRISTIANSEN

Zoological Museum, University of Copenhagen, Universitetsparken 15, DK-210o Copenhagen $\varnothing$, Denmark. 